\title{
Maraging steel prepared by supersonic aging
}

\section{マルエージング鋼の超音波熱処理}

\begin{abstract}
Byungsuk KIM, Takanori NAKAMURA, Kazuya OGURI and Yoshitake NISHI
Department of Materials Science, Tokai University, 1117 Kitakaname, Hiratsuka, Kanagawa, 259-1292 JAPAN TEL:+81-463-58-1211 (ext. 4206), FAX:+81-463-58-1812, E-mail:am026429@keyaki.cc.u-tokai.ac.jp ( Received 6, November 2000 Accepted 9, June 2001)

Effects of aging on brittleness have been investigated of the maraging steel. The supersonic aging extremely increases critical deformation diagonal $\left(\mathrm{d}_{\mathrm{C}}\right)$ and load $\left(\mathrm{P}_{\mathrm{C}}\right)$.
\end{abstract}

Key Words: Maraging steel, Vickers' indentation method, Coraps

\section{I . INTRODUCTION}

マルエージング鋼は、現存の市販鋼の中では最 も強勒材料で、超高張力鋼として、航空機、自動 車部品、ロケット部品、エヤーカー部品、モノレ ールカー部品、強カシャフト、高圧容器などに常用 されつつある。一般的にマルエージング鋼はマル テンサイト変態と時効による金属間化合物の析出 によって硬くなる。 1 この硬さの主体をなす析出物 としては $\mathrm{Ni}_{3} \mathrm{Mo}$ 型金属間化合物が挙げられる。 ${ }^{2} し$ かしながら、時効硬化現象を用いる材料強化法は、 元来時間のかかるものである。これは生産性、コ ストの面から考えてもあまり効率の良い方法とは 言えない。今回我々は、材料の高速硬化法として 新しく開発した超音波熱処理法を用いて、マルエ ージング鋼の時効硬化現象の強さと延性について 機械的性質の検討を行った。

\section{EXPERIMENTAL}

試料は板厚 $0.2 \mathrm{~mm}$ の $18 \mathrm{wt} \% \mathrm{Ni}$ マルエージング 鋼を用いた。Table 1 に試料の基本組成を示した。

TABLE1. Chemical composition of maraging steel.

\begin{tabular}{|c|c|c|c|c|c|}
\hline $\mathrm{C}$ & $\mathrm{Si}$ & $\mathrm{Mn}$ & $\mathrm{P}$ & $\mathrm{S}$ & $\mathrm{Ni}$ \\
\hline 0.071 & 0.03 & 0.04 & 0.005 & 0.003 & 18.49 \\
\cline { 1 - 5 } $\mathrm{Al}$ & $\mathrm{Ti}$ & $\mathrm{Mo}$ & $\mathrm{Co}$ & $\mathrm{Fe}$ & \\
\cline { 1 - 5 } 0.09 & 0.67 & 4.91 & 8.9 & 66.79 & mass $\%$ \\
\hline
\end{tabular}

試料の熱処理は通常の熱処理、超音波熱処理とも に773K、Ar 雰囲気中にて、それぞれ 600s、3600s、 7200 s 行い、空冷した。超音波熱処理は旭硝子株 式会社製の超音波ハンダゴテを用いて、熱処理中 絶えず超音波を直接試料に当てながら行った。熱 処理した試料の硬さ及び脆性の評価は、マイクロ ビッカース硬さ試験機を用い、圧痕を5 所打ち、
圧痕径の横長さと繸長さを 3 回ずつ測定し、その値の 平均値で硬さを評価した。 ${ }^{3}$

\section{III.RESULT \& DISCUSSION}

ビッカース硬さ試験機を用いた脆性評価法では、 コラップスが生じたときの臨界圧痕径 $\mathrm{d}_{c}$ と臨界荷 重 $\mathrm{P}_{\mathrm{c}}$ で脆性を評価する。

Figure 1 に試料の荷重と圧痕径の関係を示す。こ の図において、コラップスが生じた最低荷重 $\mathrm{P}_{\mathrm{c}}{ }^{\min }$ と、 コラップスが生じなかった最大荷重 $\mathrm{P}_{\mathrm{C}}{ }^{\mathrm{max}}$ の中点を、 臨界荷重 $\mathrm{P}_{\mathrm{c}}$ とした。同様に、コラップスが生じた最低 圧痕径の平均值 $\mathrm{d}_{\mathrm{C}}{ }^{\mathrm{min}}$ とコラップスが生じなかった最 大圧痕径の平均值 $\mathrm{d}_{\mathrm{C}}{ }^{\max }$ の中点を臨界圧痕径 $\mathrm{d}_{\mathrm{C}}$ とし た。このように、 $\mathrm{P}_{\mathrm{C}}$ と $\mathrm{d}_{\mathrm{C}}$ を定義した。

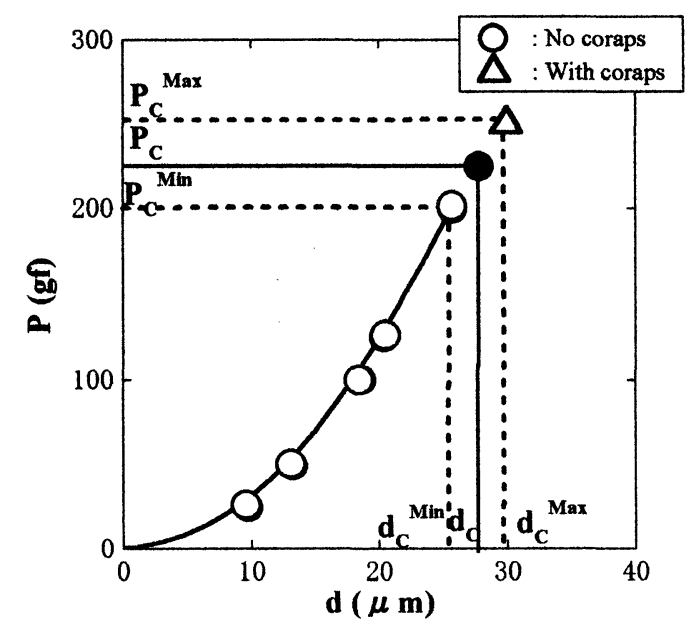

Fig.1. Change in load(P) against the diagonal(d) of a symmetric pyramidal hardness impression in a sample supersonic aged for $3.6 \times 10^{3} \mathrm{~s}$. 
Figure 2 と Fig.3 に 773K 温度で時効した試料 と超音波熱処理を行った試料の熱処理時間におけ る臨界圧痕径 $\mathrm{d}_{\mathrm{C}}$ と臨界荷重 $\mathrm{P}_{\mathrm{C}}$ の変化を示す。こ の図より、通常の熱処理と超音波熱処理ともに $3600 \mathrm{~s}$ の熱処理時間で臨界圧痕径 $\mathrm{dc}$ と臨界荷重 P $\mathrm{C}$ が最高値を示した。しかしながら、その值を比 較してみるとそれぞれ約 1.3 倍と 1.8 倍だけ超音 波熱処理の方が大きい值を示すことが分かった。 これは超音波熱処理がマルエージング鋼の強勒化 にかなり有効であることを示している。

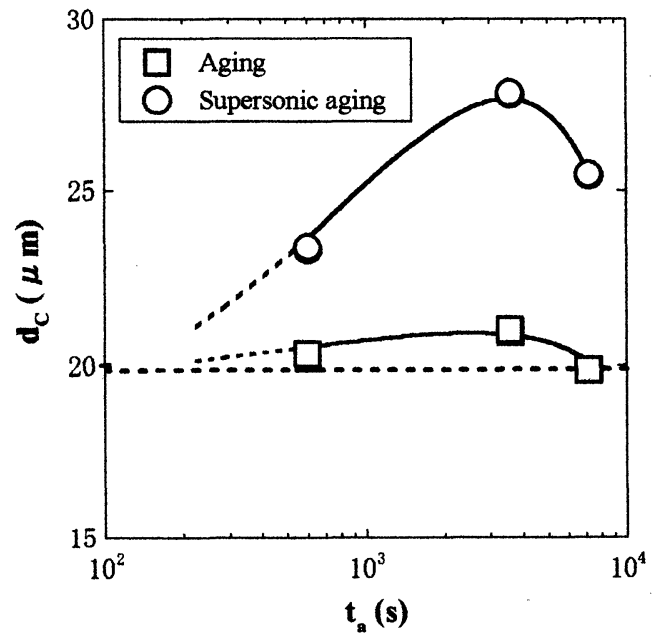

Fig.2. Change in diagonal $\left(d_{c}\right)$ against aging time $\left(t_{a}\right)$.

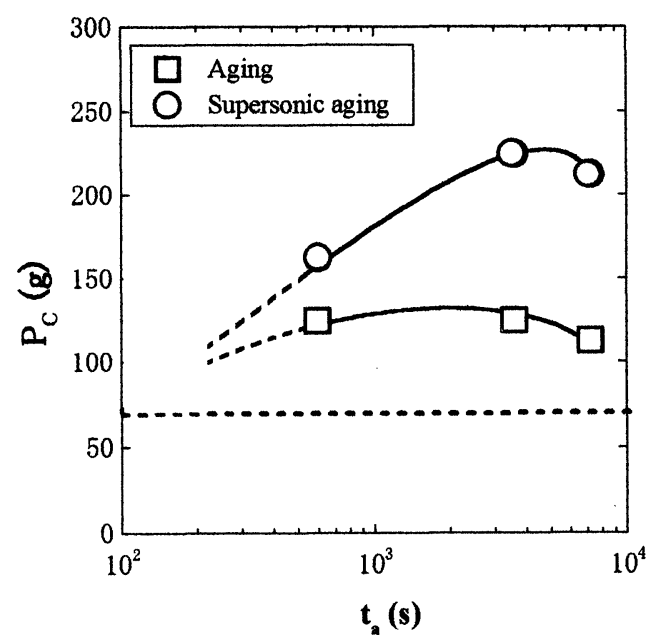

Fig.3. Change in load $\left(P_{C}\right)$ against aging time $\left(t_{a}\right)$.

\section{IV.CONCLUSION}

時効前の $18 \mathrm{wt} \% \mathrm{Ni}$ マルエージング鋼を $773 \mathrm{~K}$ で超 音波熱処理を行うと脆性が改善されることを見出し た。

\section{REFERENCES}

${ }^{1}$ Oowaku,J.Japan.Inst.Metals.3(12)(1964),pp.719-728

2 Z.Yin,H.Sato,M.nemoto,J.Echigoya,J.Japan.Inst.Metal s. Vol.47.No.1(1983),pp.48-54.

3 Y.Nishi,T.Katagiri,T.Yamano,F.Kanai,N.Ninomiya,S. Uchida,K.Oguri, T.Morishita, T.Endo,Kawakami, Appl. Phys.Lett,58(1991), pp.2084-2086. 